Provided for non-commercial research and education use. Not for reproduction, distribution or commercial use.

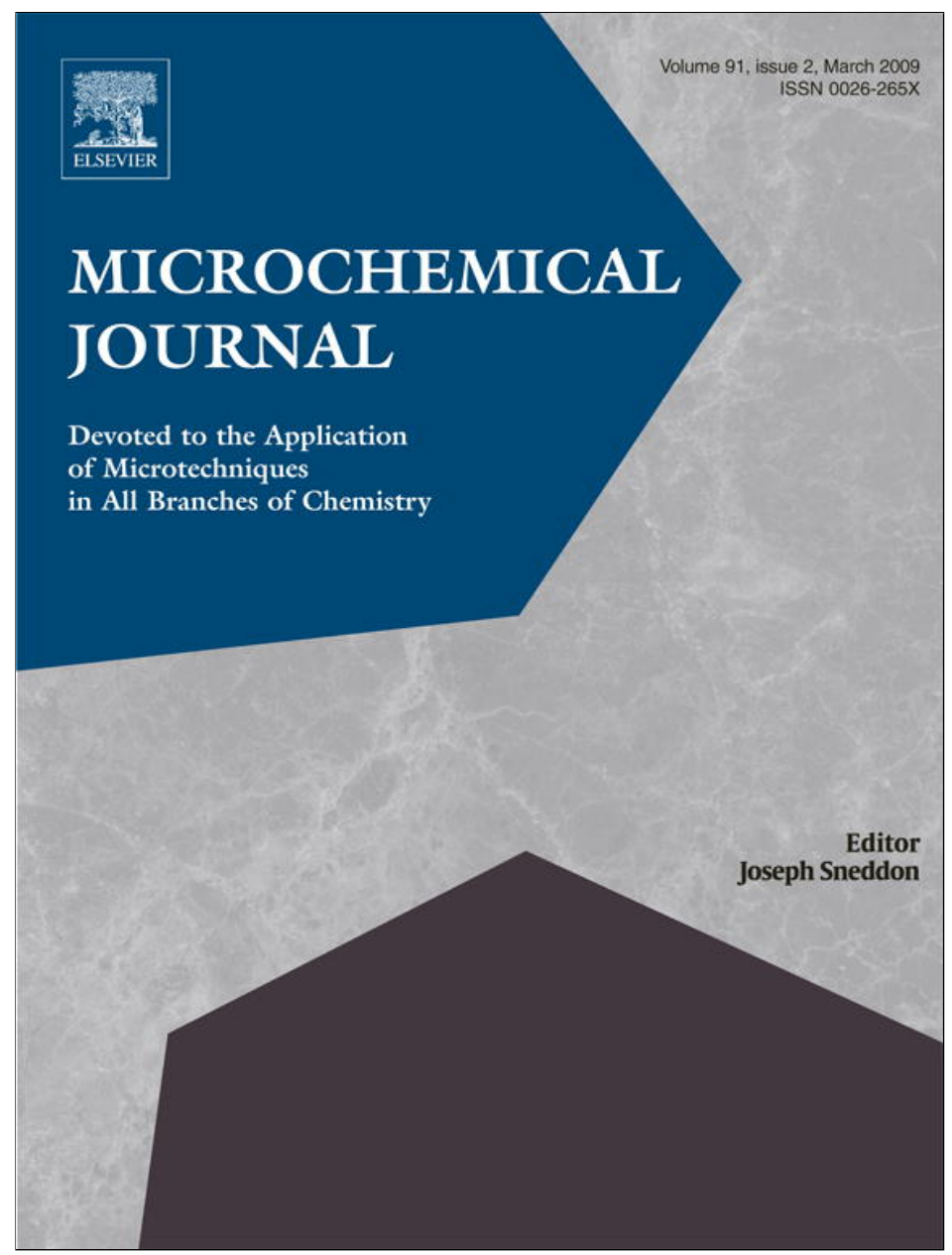

This article appeared in a journal published by Elsevier. The attached copy is furnished to the author for internal non-commercial research and education use, including for instruction at the authors institution and sharing with colleagues.

Other uses, including reproduction and distribution, or selling or licensing copies, or posting to personal, institutional or third party websites are prohibited.

In most cases authors are permitted to post their version of the article (e.g. in Word or Tex form) to their personal website or institutional repository. Authors requiring further information regarding Elsevier's archiving and manuscript policies are encouraged to visit:

http://www.elsevier.com/copyright 


\title{
Organic surface coating on Coccolithophores - Emiliania huxleyi: Its determination and implication in the marine carbon cycle
}

\author{
R.H.M. Godoi ${ }^{\text {a,* }}$, K. Aerts ${ }^{\text {a }}$, J. Harlay ${ }^{\text {b }}$, R. Kaegi ${ }^{c}$, Chul-Un Ro ${ }^{\text {d }}$, L. Chou ${ }^{\text {b }}$, R. Van Grieken ${ }^{\text {a }}$ \\ a Department of Chemistry, University of Antwerp, Universiteitsplein 1, 2610 Antwerp, Belgium \\ b Laboratoire d'Océanographie Chimique et Géochimie des Eaux, Université Libre de Bruxelles (ULB), Brussels, Belgium \\ c Swiss Federal Laboratories for Materials Testing and Research, Dubendorf, Switzerland \\ d Department of Chemistry, Inha University, Incheon 402-751, Korea
}

\section{A R T I C L E I N F O}

\section{Article history:}

Received 21 November 2008

Accepted 13 December 2008

Available online 31 December 2008

\section{Keywords:}

Emiliania huxleyi

Coccolithophores: Organic layer

SEM-EPMA

polysaccharide

\begin{abstract}
A B S T R A C T
Most of the marine precipitation of $\mathrm{CaCO}_{3}$ is due to the biological activities of planktonic and benthic organisms in waters largely oversaturated with respect to calcium carbonates. This saturation state is expected to decrease as $\mathrm{CO}_{2}$ increases in seawater. A conventional view in oceanography suggests that calcium carbonates organisms are preserved in oversaturated waters and dissolve only below the lysocline. However, it has be postulated that a fraction of the $\mathrm{CaCO}_{3}$ precipitated biogenically could dissolve in oversaturated waters due to the formation of microenvironments in which respired $\mathrm{CO}_{2}$ decreases the saturation state of seawater $(\Omega)$ in the vicinity of $\mathrm{CaCO}_{3}$ crystals. In the present study, cells of the coccolithophore Emiliania huxleyi obtained from laboratory cultures and field samples collected in the Gulf of Biscay, were examined using "variable-energy" electron-probe microanalysis, to determine the presence and thickness of their organic coating. In addition, a new approach for transferring micrometer-sized particles from a filter onto transmission electron microscope grids using manipulators was used to investigate individual coccolithophores. The dry thickness of an organic coating over the coccolithophore surface was found to range between 280 and $350 \mathrm{~nm}$. The resemblance of this coating to the carbohydrates produced and released by the cell is discussed as well as their potential for constituting a microenvironment that hosts bacteria. The properties of this organic coating and its role in the preservation/dissolution and export of biogenic carbonates in the water column are one of the major issues of carbonate geochemistry.
\end{abstract}

(C) 2009 Elsevier B.V. All rights reserved.

\section{Introduction}

The surface ocean is approximately five times oversaturated with respect to calcium carbonates. In spite of high seawater saturation meaning that precipitation is thermodynamically favorable - most of the calcium carbonates $\left(\mathrm{CaCO}_{3}\right)$ in oceanic systems are produced by marine organisms in shallow seas (corals, calcareous algae, mollusks, etc...) or in the pelagic ocean (phytoplankton, foraminifers, pteropods), and there are only few evidences for inorganic precipitation [1]. Some unicellular phytoplankton, such as the coccolithophores, is thought to be the major producers of $\mathrm{CaCO}_{3}$ in the ocean. They are capable of synthesizing minute calcites, the coccoliths (that form the coccosphere), whose presence in the water column is endangered by changes in the climate system [2-4]. Increasing human activities contribute to the rise of atmospheric carbon dioxide $\left(\mathrm{CO}_{2}\right)$ concentration, whose partial pressure $\left(\mathrm{pCO}_{2}\right)$ has increased from $280 \mu \mathrm{atm}$ in the nineteenth century to $375 \mu \mathrm{atm}$ at the present time and will

\footnotetext{
* Corresponding author.

E-mail address: rhmgodoi@hotmail.com (R.H.M. Godoi).
}

probably reach to a level higher than $700 \mu a t m$ before the next century [5]. Eight gigatons of carbon per year $\left(\mathrm{GtC} \mathrm{yr}^{-1}\right)$ are generated world wide as a result of human activity [5] and $2.2 \mathrm{Gt} \mathrm{yr}^{-1}$ of this anthropogenic carbon (C) is stored into the ocean via physical, chemical and biological processes [6,7]. Such an increase of atmospheric $\mathrm{pCO}_{2}$ leads to ocean acidification that may dramatically reduce the saturation state of seawater $(\Omega)$ with respect to calcium carbonates, therefore altering the production and fate of these biogenic minerals [8]. According to Eq. (1), precipitation of $\mathrm{CaCO}_{3}$ is a source of $\mathrm{CO}_{2}$ for seawater and, in turn, dissolution of this mineral consumes $\mathrm{CO}_{2}$ and produces alkalinity:

$$
\mathrm{Ca}^{2+}+2 \mathrm{HCO}_{3}^{-} \Leftrightarrow \mathrm{CaCO}_{3}+\mathrm{CO}_{2}+\mathrm{H}_{2} \mathrm{O}
$$

Hence, the production and dissolution of $\mathrm{CaCO}_{3}$ may be considered as a major process in the oceanic $\mathrm{C}$ cycle for future climate prediction based on global climate models.

As stated by Milliman and coworkers [9], a long-standing paradigm in oceanography was the conservative behavior of pelagic calcium carbonates and their dissolution at depths below the lysocline [10]. However, some evidences of dissolution - of up to half of the $\mathrm{CaCO}_{3}$ 
BELGICA BG2003/12 CRUISE

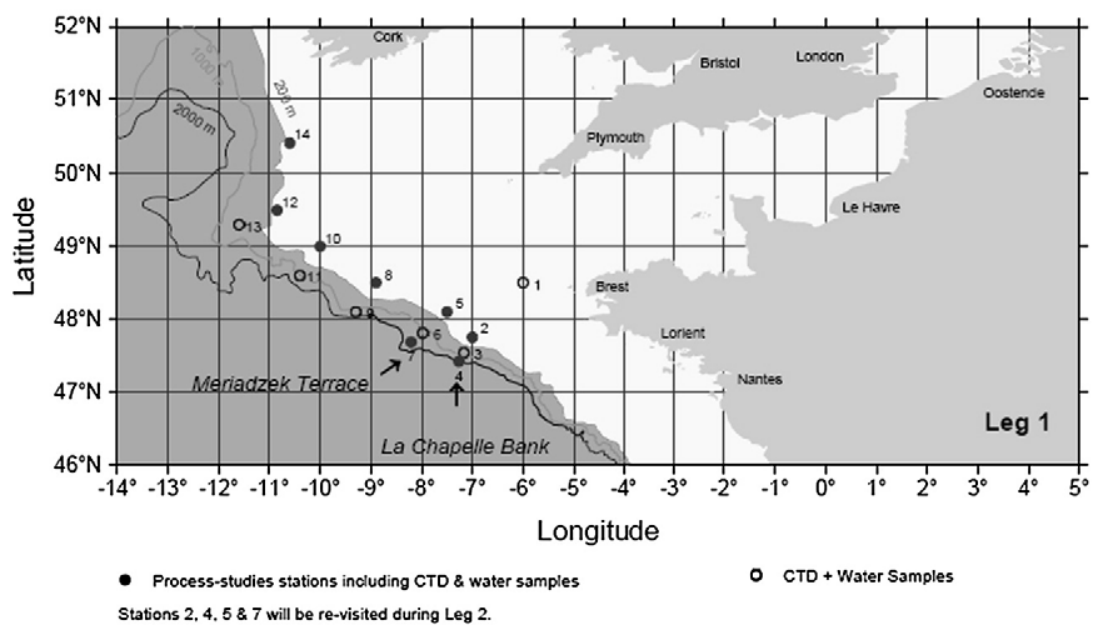

Fig. 1. Sampling locations during the 2003 Belgica Cruise in the Bay of Biscay.

produced in the sunlit layer - are also observed in the surface ocean [1113] and presumably in the photic layer during coccolithophorid blooms [14]. One of the hypotheses proposed by researchers to interpret supralysocline dissolution of $\mathrm{CaCO}_{3}$ is its occurrence in the gut and the fecal pellets of zooplankton. However, in natural bloom conditions, only $15 \%$ of $\mathrm{CaCO}_{3}$ may be dissolved, based on model simulations [15]. Another hypothesis suggests the formation of microenvironments that may mitigate $\mathrm{CaCO}_{3}$ preservation in the water column [9].

The "microenvironment" hypothesis for $\mathrm{CaCO}_{3}$ preservation relies on the formation of an interface between the surface of crystals and seawater, which can be of inorganic and/or organic origin [16]. The formation of Mg-calcite layers at the surface of calcite minerals was observed by Wollast et al. [17]. As a strong inhibitor for the growth of calcite crystals [14]), Mg ions in the surrounding calcite lattice create a less stable layer that may dissolve at lower depth than calcite. Conversely, an organic film adsorbed onto aragonite inhibited the precipitation of this phase in surface seawater off Bermuda [18]. Thirty years later, Troy et al. [11] observed an organic coating adsorbed onto calcite surfaces and correlated its thickness, determined by atomic force microscopy (AFM), with dissolved organic carbon concentration (DOC) along a vertical profile in the North Pacific. The reaction of $\mathrm{CaCO}_{3}$ with seawater appears to be strongly dependant on the presence of organic compounds at the $\mathrm{CaCO}_{3} /$ seawater interface.

An organic coating around coccospheres of Emiliania huxleyi has been documented in recent studies [19-21], but hitherto no investigation dedicated to the evaluation of its thickness and/or composition has been reported. The characterization of a coating around the coccosphere may provide evidence for the presence of microenvironments, which may influence calcite preservation above or below the lysocline, favoring or preventing calcite dissolution. We believe that this organic coating is related to the production and the extracellular release of carbohydrates associated to biogenic calcification. Therefore the aim of the current study was to attempt an independent assessment of the thickness of the organic coating of E. huxleyi. The heterogeneity of the structural composition of particles (individual cells of E. huxleyi in this study) was estimated by electron-probe microanalysis (EPMA) for which X-ray photons obtained at different primary electron beam energies provided the chemical compositions of different regions of the cell. The application of a quantification method based on Monte Carlo simulation [22], allowed the calculation of the apparent thickness of the organic coating of some different $E$. huxleyi's coccospheres (natural and cultured ones). To our knowledge, this is the first time that EPMA has been used to investigate in situ the presence of an organic layer on the coccolithophore E. huxleyi.

\section{Materials and Methods}

\subsection{Study material}

Coccolithophores are unicellular marine calcifying phytoplankton able to produce large blooms in the open and coastal oceans. They are one of the main contemporary producers of $\mathrm{CaCO}_{3}$-calcite on earth. Their organic cell is surrounded by minute calcite scales (coccoliths) that are secreted continuously during their cell-cycle [23]. They are assembled around the organic cell with organic cement and are continuously released as new ones are produced [24]. Individual cells of E. huxleyi obtained from cultures and sampled during two different stages of a natural bloom were analyzed for assessing the thickness of their organic coating.

\subsection{Laboratory culture}

In the laboratory, E. huxleyi (English Channel's strain BDV1 - AC481 from ALGOBANK - University of Caen, France) was grown in a batch of nutrient-enriched filtered and sterilized natural north-Atlantic seawater, in a thermostatized incubator at $13{ }^{\circ} \mathrm{C}$, under irradiance of $150 \mu \mathrm{mol} \mathrm{m} \mathrm{m}^{-2} \mathrm{~s}^{-1}$ and a light:dark cycle of $14 \mathrm{~h}: 10 \mathrm{~h}$. Nutrient concentrations with an initial N:P molar ratio of 30:1 were used, here, to enhance calcification of the species (30 $\mu \mathrm{M}$ nitrate and $1 \mu \mathrm{M}$ phosphate). The samples $(2 \mathrm{ml}$ ) were harvested at the end of the exponential growth phase, during the calcification phase (after a decrease in measured total alkalinity, which is not shown here), and filtered under low vacuum through $0.4 \mu \mathrm{m}$ polycarbonate Nuclepore filters.

\subsection{Field sampling and sample treatment}

In the field, suspended matter was collected within a coccolithophore bloom in the Northern Bay of Biscay (off Brittany, France) during the cruise of the RV Belgica from April 28 to May 16 2003. The locations of the sampling stations (Fig. 1) were determined to cover different stages of the bloom, based on remote sensing data (images not shown). The sampling was performed at stations 5 (early stage) and station 14 (late stage) using a CTD rosette system equipped with 10 -litres Niskin bottles. The bottles were rinsed 3 times with Milli-Q water and 3 times with water from each sampling point before collection. The samples were filtered immediately after collection to prevent interaction between dissolved and suspended phases in the storage bottles. Filtration was performed gravimetrically through 


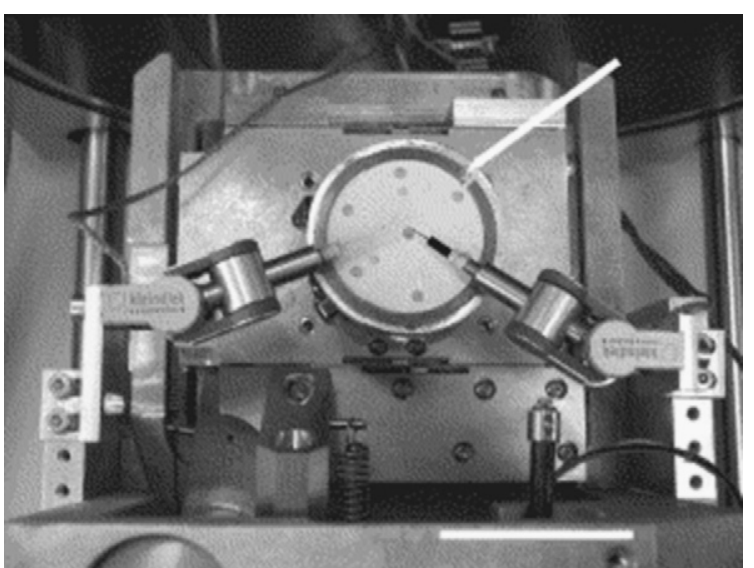

Fig. 2. Manipulators within the ESEM-sample chamber. Scale bar is $5 \mathrm{~cm}$.

$0.4 \mu \mathrm{m}$ polycarbonate Nuclepore filters to avoid the damage of $E$. huxleyi. A suitable cell density of $E$. huxleyi for analysis was obtained by filtering $100 \mathrm{ml}$ of surface seawater.

In order to avoid salt crystallisation on the filters obtained from laboratory and field samplings, all the filters were rinsed 3 times with $50 \mathrm{ml}$ of the $0.05 \mathrm{M} \mathrm{NH}_{4} \mathrm{HCO}_{3}$ buffer. The filters were then placed in Petri dishes, air dried and stored in a deep-freezer until measurement on the EPMA.

\subsection{Instrumentation}

In order to investigate single cells of E. huxleyi, a new approach for transferring micrometer-sized particles between different sample holders using manipulators was developed [25]. The selected particles were transported from a polycarbonate membrane filter to a carbonfree substrate (pure silicon wafer), with glass needles of $100 \mathrm{~nm}$ attached to manipulators to avoid the carbon interference from Nuclepore filters (Fig. 2). A detailed description of the technique, technical information about the manipulators and possible applications can be found elsewhere ([25] and references therein). The coccospheres were placed next to each other on a silicon wafer substrate, as shown in Fig. 3. Figs. 4 and 5 illustrate the shape and characteristic appearance of the malformed and healthy coccospheres of $E$. huxleyi investigated in this work. The analyses of individual particles (E. huxleyi) transferred to the silicon wafer were carried out using a JEOL 733 electron probe microanalyzer equipped with an Oxford energy dispersive X-ray detector. The $\mathrm{Si}(\mathrm{Li})$ detector is equipped with an Oxford atmospheric ultrathin window of $0.2 \mu \mathrm{m}$. The resolution of the detector is $133 \mathrm{eV}$

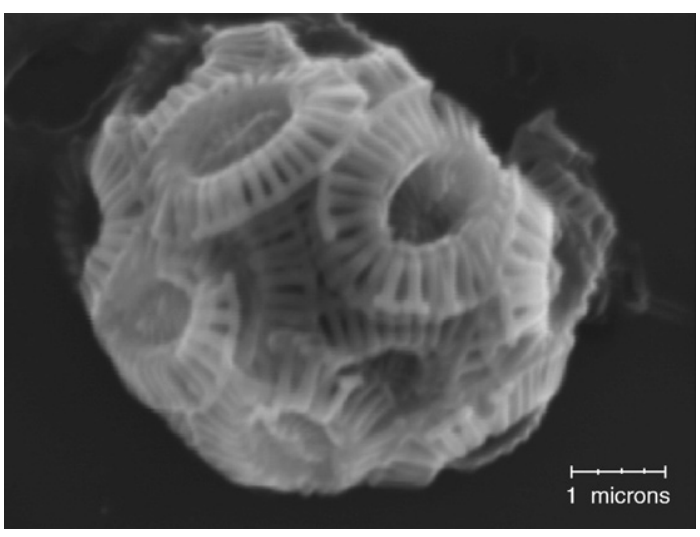

Fig. 4. SEM image showing a mal-formed coccosphere (E. huxleyi) from bloom station 14 collected on a polycarbonate filter.

for Mn K $\alpha$ X-rays. The spectra were recorded by a Canberra S100 multichannel analyzer controlled by a software developed in-house. Measurements of individual particles were carried out manually in the point analysis mode. Four X-ray spectra at 5, 10, 15, and $20 \mathrm{keV}$ using a beam current of $1.0 \mathrm{nA}$ were acquired for each particle. In order to obtain enough counts in the X-ray spectra for statistical analysis, a measuring time of $20 \mathrm{~s}$ was used [26].

This approach allowed the combinational use of microanalytical techniques for detailed analysis of specific particles, enabling the characterisation of these particles without the interference of the polycarbonate substrate.

All twelve individual E. huxleyi cells of similar sizes (approximately $7 \mu \mathrm{m}$ ) from the laboratory cultures and the oceanic waters were analyzed in this manner. In addition, the measurement was carried out at around $-193{ }^{\circ} \mathrm{C}$ using the cold stage of the electron microprobe cooled by liquid nitrogen, which enabled minimal beam damage to the sample.

The net X-ray intensities for the elements were obtained by nonlinear least-squares fitting of the collected spectra using the AXIL program [27]. The elemental concentrations of individual particles were determined from their X-ray intensities, by the application of a Monte Carlo calculation combined with reverse successive approximations [28]. The Monte Carlo calculation is based on a modified version of the single scattering CASINO Monte Carlo program, which was designed for low-energy beam interaction generating X-ray and electron signals. The modified version of the CASINO program allows the simulation of electron trajectories in spherical, hemispherical, and hexahedral particles located on a flat substrate. The simulation procedure

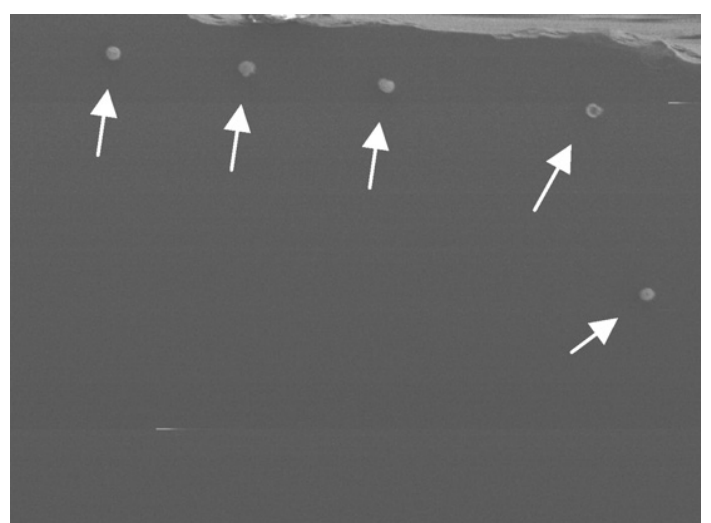

Fig. 3. SEM image showing an overview of the cells of E. huxleyi transferred to the silicon wafer substrate.

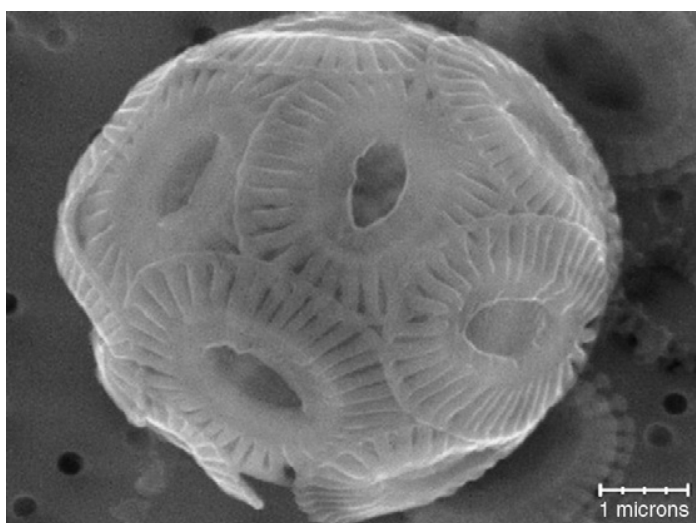

Fig. 5. SEM image showing a healthy coccosphere (E. huxleyi) from the bloom station 5 collected on a polycarbonate filter. 


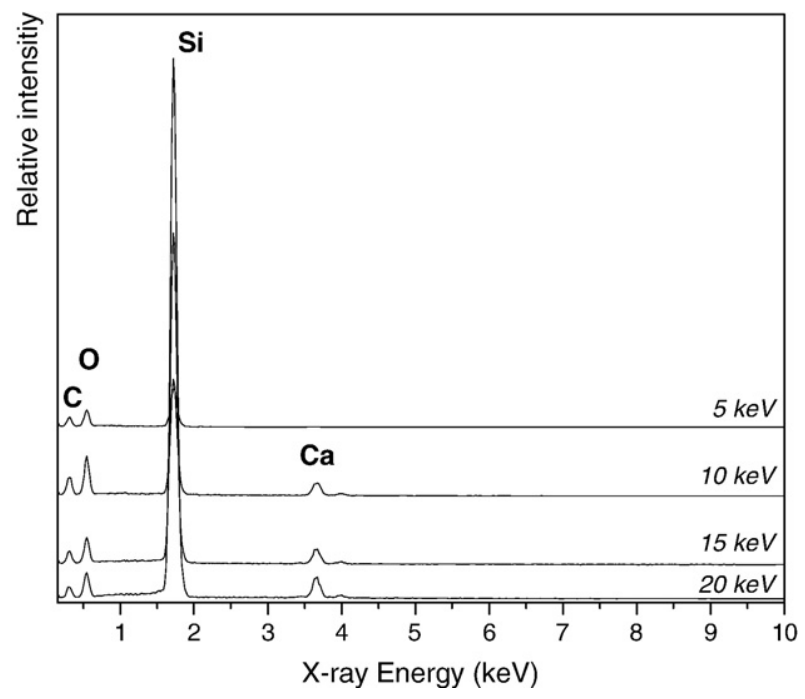

Fig. 6. X-ray spectra obtained from intact $E$. huxleyi of $7 \mu \mathrm{m}$ diameter transferred to the Si wafer substrate at 5, 10, 15, and $20 \mathrm{keV}$ accelerating voltages for a field sample.

determines also the characteristic and continuous X-ray flux emitted from the substrate material and the influence of the substrate material on the energy distribution of the exciting electrons. The quantification procedure uses an iterative approach; the iterative calculation is finished when measured X-ray intensities for all chemical elements in a particle are well matched to intensities simulated by the Monte Carlo calculation. In the beginning of the iterative Monte Carlo calculation, the differences between measured and calculated intensities are considerable so that a successive approximation approach is employed to find the best match, with adjusting input values, e.g., chemical compositions, for the following iteration. When convergency is achieved, the chemical compositions used for the calculation is the obtained chemical composition of the particle. Generally a few iterations are enough to find convergency. More details on the quantification procedure can be found elsewhere ([22] and references therein).

The concentration data are the outputs of the iterative Monte Carlo calculation program that yields atomic concentrations of particles from X-ray spectral data. For heterogeneous particles that have different chemical species in different layers, the use of different energies of the primary electron beam is expected to provide useful information on the in-depth heterogeneity of the particles. This is mainly because of the different excitation volumes associated with the energies of the primary electron beam [22].

\section{Results and Discussion}

The detection of characteristic X-rays is a non-linear function of several factors. One has to take into account the heterogeneity and the geometric effect of the samples. The modified Monte Carlo simulation was therefore applied to explain the heterogeneous composition of $E$. huxleyi, derived from the measurements. For a comparison of measured data with the simulation results, a total of five culture samples and seven field samples (five intact and two malformed) were measured as mentioned above.

Fig. 6 shows that the measured characteristic X-ray intensities for the elements in the coccosphere and the substrate vary with the primary electron beam energies. The intensities of $\mathrm{Ca}$ and $\mathrm{Si}$ increase with increasing electron beam energy, whereas those of carbon and oxygen fluctuate as a function of the excitation voltage. Since $\mathrm{CaCO}_{3}$ species is below an organic coating, Ca intensity increases with increasing electron beam energy, i.e. electron penetration depth increases with the increase of electron beam energy so that characteristic Ca X-rays are generated more at higher electron beam energy. Since the generated
Ca X-rays can be detected without the loss by a significant absorption while they travel through the coccosphere before the detection, $\mathrm{Ca}$ intensities linearly increase with the increase of electron beam energy. The same is for characteristic Si X-rays. However, C and O intensities are at minimum for $5 \mathrm{keV}$ and at maximum for $10 \mathrm{keV}$ among $5,10,15$, and $20 \mathrm{keV}$ electron beam energies. With the increase of electron beam energy, electron penetration depth also increases, resulting in the generation of characteristic $\mathrm{C}$ and $\mathrm{OX}$-rays at deeper region, i.e. below an organic coating. Since the characteristic C and OX-rays have low energy, those are significantly absorbed in the coccosphere before detection and if they were generated deeper then they would be observed more in the coccosphere. That is why maximal intensities for $\mathrm{C}$ and $\mathrm{O}$ were observed for $10 \mathrm{keV}$. We performed Monte Carlo calculations by assuming that $\mathrm{C}$ and $\mathrm{O}$ compositions of the surface organic coating were $75 \%$ : $25 \%, 67 \%$ : $33 \%, 50 \%$ : 50\%, and 33\%: $67 \%$ in atomic fraction. The chemical composition of C: $\mathrm{O}=50 \%: 50 \%$ gave the best fit for the measured intensities, although there was still minor discrepancy between the measured and simulated intensities.

Previous studies demonstrated that the quantification methodology used in this investigation, produces quite reliable elemental concentrations, with an accuracy of better than $10 \%$ in atomic fraction ([22] and references therein). The Monte Carlo calculation was applied to determine the thickness of organic surface regions, assuming a homogeneous organic layer (C: $\mathrm{O}=50 \%$ : $50 \%$ ) over the coccospheres (calcite scales). This procedure provides the X-ray intensity for each element when the assumed thickness of the organic surface layer is given as an input parameter. Ratios of simulated-to-measured intensities as a function of the assumed organic surface thickness for a coccosphere of $7.0 \mu \mathrm{m}$ diameter are shown in Fig. 7 for an accelerating voltage of $10 \mathrm{keV}$.

The ratios for calcium, carbon and oxygen between the simulated and measured intensities, are strongly dependent on the assumed thickness of the surface organic layer. For oxygen, this ratio decreases with decreasing the assumed thickness of the organic layer. In contrast, the ratio for calcium increases as the thickness of the organic layer decreases. The ratios for carbon decreases clearly with increasing assumed thickness of the organic layer. By looking at the $\mathrm{C}$ and $\mathrm{O}$ behavior according to the thickness, it appears that the carbon disproportion can be related with certain calcite scales decalcification (polymorphism). We assume this result is an effective evidence for the assumed heterogeneity of the E. huxleyi. For the E. huxleyi, the oxygen species is in the surface region, calcium is in the core region, and the carbon concentration in the $\mathrm{CaCO}_{3}$ core region is higher than that in organic surface region.

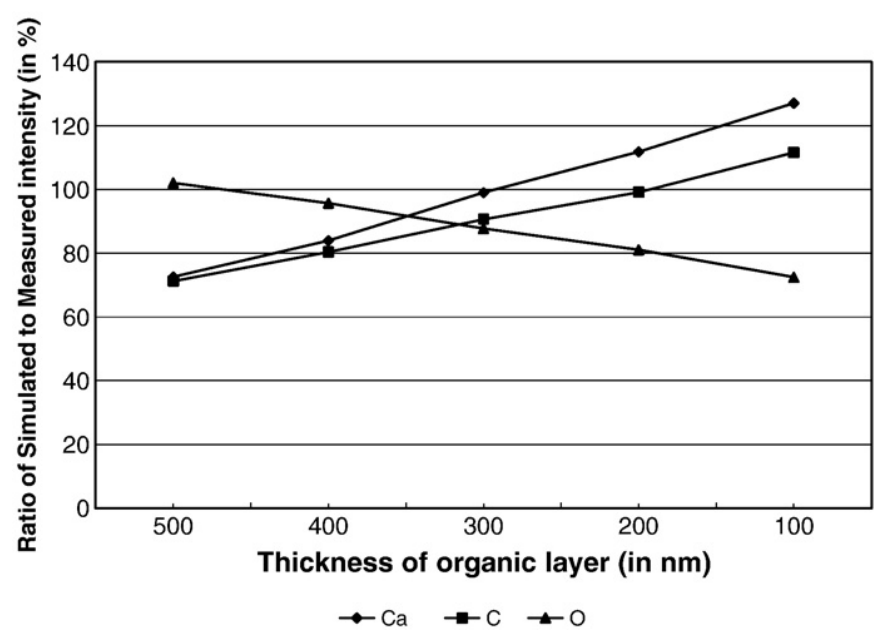

Fig. 7. Variation of the ratios between the simulated and measured X-ray intensities as a function of assumed dry organic surface thicknesses (in $\mathrm{nm}$ ) for an intact coccosphere, at a $10 \mathrm{keV}$ acceleration voltage. 
Table 1

Estimated dry organic layer thickness for various coccospheres obtained with $10 \mathrm{keV}$ excitation energy

\begin{tabular}{|c|c|c|c|c|c|c|}
\hline & \multicolumn{6}{|c|}{ Particle no. } \\
\hline & 1 & 2 & 3 & 4 & 5 & average \\
\hline \multicolumn{7}{|c|}{ Estimated thickness of organic layer, $\mathrm{nm}$} \\
\hline Cultured coccosphere & $270-290$ & $<100$ & $340-360$ & $280-300$ & $230-250$ & $280-300$ \\
\hline $\begin{array}{l}\text { Malformed } \\
\text { coccosphere }\end{array}$ & $300-320$ & $280-300$ & - & - & - & 300 \\
\hline Intact coccosphere & $390-410$ & $340-350$ & $290-310$ & $290-310$ & $300-320$ & $330-350$ \\
\hline
\end{tabular}

From the results shown in Fig. 7, a reasonable thickness in the range of 340-350 nm of the dry surface region is measured. Similarly, the thickness of organic layer at the surface for all samples analyzed can be evaluated. The values of estimated thickness are summarized in Table 1 for three different types of coccospheres. The surface coating appears to be relatively constant, showing an average thickness of $280-300 \mathrm{~nm}, 300 \mathrm{~nm}$ and $330-350 \mathrm{~nm}$, respectively for intact coccospheres from the laboratory culture, the malformed and the intact coccospheres from the field samplings.

The measurement of this external coating has been made possible because it is rich in carbon and oxygen. Carbon-rich compounds are known to be produced and subsequently excreted by the cells $[29,30]$. Among these C-rich metabolites produced and released by E. huxleyi, low molecular weight polysaccharides are probably the better candidates for constituting the organic coating analyzed here, due to their metabolism and properties.

Calcareous algae, such as the coccolithophore E. huxleyi, require specific polysaccharides for carrying out the calcification process $[31,32]$. In the specific case of internal calcification by Coccolithophoraceae, the coccolith is formed in Golgi-derived vesicles within the cell [33-35] and is extruded through the plasmalemna, before being incorporated into the coccosphere. Coccoliths are produced continuously at a rate of 1 coccolith every 3 hours, under field conditions [24] and form 1 to 3 layers around the naked cell [23]. The external coccoliths detach as a new layer of coccoliths is extruded by the cell. This process results in the accumulation of loose coccoliths in surface waters that modifies the optical properties of the seawater (whitening) [36]. The acidic nature of the coccolithophorid polysaccharides allows them to have a strong affinity for bivalent cations such as calcium $[37,38]$. Due to this property, the coccolith associated polysaccharides (CP) exert a strong control on the growth and the shape of coccoliths $[34,39]$. Immunochemical localization of $\mathrm{CP}$ showed that such polysaccharides were associated with the coccoliths within the cell and were extruded together with the coccolith to the coccosphere in $E$.

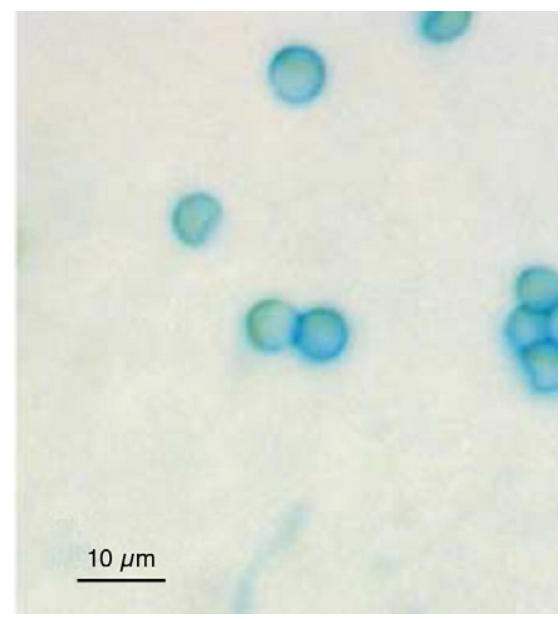

Fig. 8. Optical microscopy image showing coccolithophorid cells (E. huxleyi) stained with Alcian Blue (courtesy of A. Engel, unpub. data).

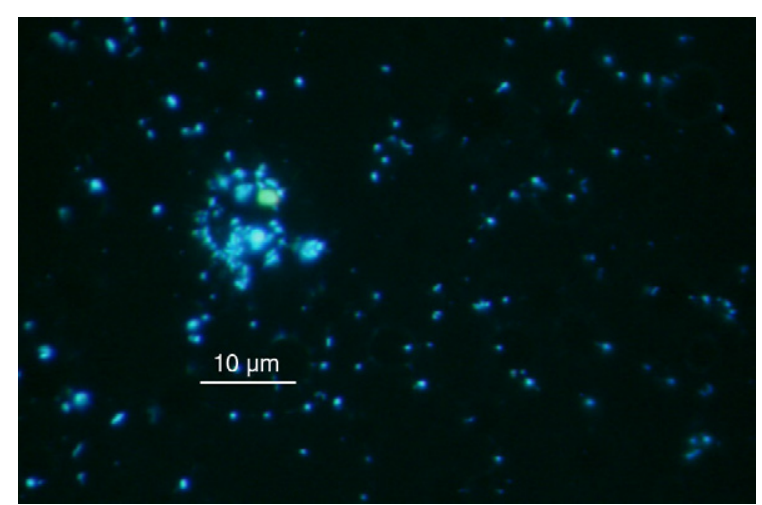

Fig. 9. DAPI-stained bacteria (light-blue dots) in the coccosphere of a cell of E. huxleyi observed using epifluorescence microscopy.

huxleyi [40] and Pleurochrysis carterae [41]. The presence of CP in the coccosphere is deduced (Fig. 8) from a microscopic preparation for transparent exopolymer particles (TEP) analysis. The coccospheres were stained with Alcian Blue, a cationic copper phthalocyanine dye that complexes carboxyl and half-ester sulfate reactive groups of acidic polysaccharides [42]. The affinity of acidic polysaccharides for this dye allowed its semi-quantitative determination of TEP concentration [43] and direct observation of TEP on colored slides [44].

In the light of the present study, one can relate this organic coating to the presence of acidic polysaccharides and its potential transformation into TEP. However, due to the complex interaction between polysaccharides and calcite crystals, it is not clear whether such polysaccharides act to preserve or dissolve biogenic calcite $[21,39,45,46]$. The association of bacteria to the coccosphere (Fig. 9) suggests that the organic coating may serve, at least, as a physical substrate hosting bacteria. In the extreme cases, the bacterial biomass around the coccosphere may be fueled by organic compounds in the coating. The release of $\mathrm{CO}_{2}$ during bacterial respiration causes the decrease of $\Omega$ into the cell's microenvironment and, hence, may favor $\mathrm{CaCO}_{3}$ dissolution and the breaking parts of coccoliths.

Finally, the adhesive properties of the organic coating may interact with suspended matter in the water column to produce larger aggregates whose sinking velocities can be further increased due to the ballast effect provided by the associated exogenous minerals $[47,48]$.

\section{Conclusions}

Our results provide strong evidence for the presence of an organic coating around coccospheres of the coccolithophore E. huxleyi by estimating its thickness on dried material. The nature of this coating is discussed and some ancillary observations confirm that the organic coating may firstly be composed of polysaccharides. Their resemblance to the polysaccharides involved in the internal calcification is affirmed from immuno-localization studies. The coating provides furthermore a physical substrate (at least) for bacterial assemblages, whose specific composition needs to be established.

By reducing exchanges between mineral surfaces and surrounding seawater, the presence of this organic coating is hypothesized to constitute a microenvironment that may play a role in carbonate preservation/dissolution in the water column. Interestingly, in association with bacteria, reducing the diffusion of respired $\mathrm{CO}_{2}$ in the vicinity of the cell and, hence, lowering the saturation state $(\Omega)$ with respect to carbonate phases, is thought to favor supralysocline dissolution of $\mathrm{CaCO}_{3}$. The adhesive properties of the polysaccharides and the ballast of calcite make them prone to self-assembly of fast-sinking aggregates. These hypotheses converge with the preliminary works of Milliman et al. (1999) for biologically mediated dissolution of calcium carbonates. The potential implication of the transformation of the dissolved 
organosulfur, dimethylsulfonio-propionate (DMSP), into the volatile dimethylsulfide (DMS) within the coccosphere is not discarded from our interest since coccolithophorid blooms are great producers of these substances $[49,50]$. Such hypotheses reinforce the role of coccolithophores in the oceanic carbon cycle and provide new insights for predicting interactions between calcifying phytoplankton and seawater under climate change and more acidic oceanic conditions.

The approach presented here can thus be used to resolve the complex structure of single particles, including phytoplankton, to refine heterogeneity measurements based on single particle analysis.

\section{Acknowledgments}

We would like to thank the officers and crewmembers of the RV Belgica for their logistic support on board the ship during the survey conducted in the northern Bay of Biscay. This study was funded by the Belgian Federal Science Policy Office in the framework of the CCCC project (Contract No. EV/5). This is also a contribution to the EU FP6 European Network of Excellence EUR-OCEANS (contract no. 5111062) and IP CarboOcean (contract no. 511176-2). The present work is a Belgian input to the SOLAS international research initiative.

\section{References}

[1] J.W. Morse, R.A. Berner, Dissolution kinetics of calcium carbonate in sea water: II A kinetic origin for the lysocline, Am. J. Sci. 272 (1972) 840-851.

[2] R.A. Feely, C.L. Sabine, K. Lee, W. Berelson, J. Kleypas, V.J. Fabry, F.J. Millero, Impact of anthropogenic $\mathrm{CO}_{2}$ on the $\mathrm{CaCO}_{3}$ system in the oceans, Science 305 (2004) 362-366.

[3] U. Riebesell, I. Zondervan, B. Rost, P.D. Tortell, R.E. Zeebe, F.M.M. Morel, Reduced calcification of marine plankton in response of increased atmospheric $\mathrm{CO}_{2}$, Nature 407 (2000) 364-367.

[4] J.-P. Gattuso, R.W. Buddemeier, Calcification and $\mathrm{CO}_{2}$, Nature 407 (2000) 311-312.

[5] IPCC. Climate Change 2007: The Physical Science Basis. Contribution of Working Group I to the Fourth Assessment Report of the Intergovernmental Panel on Climate Change. S.D. Solomon, D. Qin, M. Manning, Z. Chen, M. Marquis, K. B. Averyt, M. Tignor, H. L. Miller. 996pp. 2007. Cambridge (UK) and New York (NY USA), Cambridge University Press.

[6] R.A. Berner, The long-term carbon cycle, fossil fuels and atmospheric composition, Nature 426 (2003) 323-326.

[7] C.L. Sabine, R.A. Feely, N. Gruber, R.M. Key, K. Lee, J.L. Bullister, R. Wanninkhof, C.S. Wong, D.W.R. Wallace, B. Tilbrook, F.J. Millero, T.H. Peng, A. Kozyr, T. Ono, A.F. Rios, The oceanic sink for anthropogenic $\mathrm{CO}_{2}$, Science 305 (2004) 367-371.

[8] The Royal Society, Ocean acidification due to increasing atmospheric carbon dioxide, The Royal Society, London, 2005 [Policy Report 12/05] Ref Type: Report.

[9] J.D. Milliman, P.J. Troy, W.M. Balch, A.K. Adams, Y.H. Li, F.T. Mackenzie, Biologically mediated dissolution of calcium carbonate above the chemical lysocline? DeepSea Res. I 46 (1999) 1653-1669.

[10] J.W. Morse, D.K. Gledhill, F.J. Millero, $\mathrm{CaCO}_{3}$ precipitation kinetics in waters from the great Bahama bank: Implications for the relationship between bank hydrochemistry and whitings, Geochim. Cosmochim. Acta 67 (2003) 2819-2826.

[11] P.J. Troy, Y.-H. Li, F.T. Mackenzie, Changes in Surface Morphology of Calcite Exposed to the Oceanic Water Column, Aquat. Geochem. 3 (1997) 1-20.

[12] R. Wollast, L. Chou, Distribution and fluxes of calcium carbonate along the continental margin in the Gulf of Biscay, Aquat. Geochem. 4 (1998) 369-393.

[13] R.E. Zeebe, P. Westbroek, A simple model for the $\mathrm{CaCO} 3$ saturation state of the ocean: The "Strangelove," the "Neritan," and the "Cretan" Ocean, Geochem. Geophys. Geosyst. 4 (2005) 1104.

[14] R.A. Berner, The role of magnesium in the crystal growth of calcite and aragonite from sea water, Geochim. Cosmochim. Acta 39 (1975) 489-494.

[15] H. Jansen, D.A. Wolf-Gladrow, Carbonate dissolution in copepod guts: a numerical model, Mar. Ecol. Prog. Ser. 221 (2001) 199-207.

[16] R.A. Jahnke, D.B. Craven, J.-F. Gaillard, The influence of organic matter diagenesis on $\mathrm{CaCO}_{3}$ dissolution at the deep-sea floor, Geochim. Cosmochim. Acta 58 (1994) 2799-2809.

[17] R. Wollast, R.M. Garrels, F.T. Mackenzie, Calcite-seawater reactions in ocean surface waters, Am. J. Sci. 280 (1980) 831-848.

[18] K.E. Chave, E. Suess, Calcium Carbonate Saturation in Seawater: Effects of Dissolved Organic Matter, Limnol. Oceanogr. 15u (1970) 633-637.

[19] J.R. Young, S.A. Davis, P.R. Bown, S. Mann, Coccolith ultrastructure and biomineralisation, J. Struct. Biol. 126 (1999) 195-215.

[20] A. Engel, B. Delille, S. Jacquet, U. Riebesell, E. Rochelle-Newall, A. Terbruggen, I. Zondervan, Transparent exopolymer particles and dissolved organic carbon production by Emiliania huxleyi exposed to different $\mathrm{CO}_{2}$ concentrations: a mesocosm experiment, AME 34 (2004) 93-104.

[21] Y. Hirokawa, S. Fujiwara, M. Tsuzuki, Three Types of Acidic Polysaccharides Associated with Coccolith of Pleurochrysis haptonemofera: Comparison with Pleurochrysis carterae and Analysis Using Fluorescein-Isothiocyanate-Labeled Lectins, Mar. Biotechnol. 7 (2005) 634-644.
[22] C.U. Ro, K.Y. Oh, J. Osan, J. de Hoog, A. Worobiec, R. Van Grieken, Heterogeneity assessment in individual CaCO3-CaSO4 particles using ultrathin window electron probe X-ray microanalysis, Anal. Chem. 73 (2001) 4574-4583.

[23] E. Paasche, A review of the coccolithophorid Emiliania huxleyi (Prymnesiophyceae), with particular reference to growth, coccolith formation, and calcification-photosynthesis interactions, Phycology 40 (2002) 503-529.

[24] J.J. Fritz, Carbon fixation and coccolith detachment in the coccolithophore Emiliania huxleyi in nitrate-limited cyclostats, Mar. Biotechnol. 133 (1999) 509-518.

[25] R.H.M. Godoi, S. Potgieter-Vermaak, J. de Hoog, R. Kaegi, R. Van Grieken, Substrate selection for optimum qualitative and quantitative single atmospheric particles analysis using nano-manipulation, sequential thin-window electron probe X-ray microanalysis and micro-Raman spectrometry, Spectrochim. Acta, Part B 61 (2006) 375-388.

[26] S. Hoornaert, R.H.M. Godoi, R. Van Grieken, Elemental and single particle aerosol characterisation at a background station in Kazakhstan, J. Atmos. Chem. 48 (2004) 301-305.

[27] B. Vekemans, K. Janssens, L. Vincze, F. Adams, P. Van Espen, Analysis of X-ray spectra by iterative least squares (AXIL): New developments, X-Ray Spectrom. 23 (1994) 278-285.

[28] C.U. Ro, H. Kim, R. Van Grieken, An expert system for chemical speciation of individual particles using low-Z particle electron probe X-ray microanalysis data, Anal. Chem. 76 (2004) 1322-1327.

[29] E. Fernández, J.J. Fritz, W.M. Balch, Chemical composition of the coccolithophorid Emiliania huxleyi under light-limited steady state growth, J. Exp. Biol. Ecol. 207 (1996) 149-160

[30] E. Fernández, E. Marañon, W.M. Balch, Intracellular carbon partitioning in the coccolithophorid Emiliania huxleyi, J. Mar. Syst. 9 (1996) 57-66.

[31] M.I. Bilan, A.I. Usov, Polysaccharides of Calcareous Algae and Their Effect on the Calcification Process, Bioorg. Khim. 27 (2001) 2-16.

[32] P. van der Wal, E.W. de Jong, P. Westbroek, W.C. de Bruijn, A.A. Mulder-Stapel, Ultrastructural polysaccharide localization in calcifying and naked cells of the coccolithophorid Emiliania huxleyi, Protoplasma 118 (1983) 157-168.

[33] E.W. de Jong, L. Bosch, P. Westbroek, Isolation and characterisation of a $\mathrm{Ca}^{2+}$-binding polysaccharide associated with coccoliths of Emiliania huxleyi (Lohmann) Kamptner, Eur. J. Biochem. 70 (1976) 611-621.

[34] A.H. Borman, E.W. de Jong, M. Huizinga, D.J. Kok, P. Westbroek, L. Bosch, The role in $\mathrm{CaCO} 3$ crystallization of an acid $\mathrm{Ca} 2+$-binding polysaccharide associated with coccoliths of Emiliania huxleyi, Eur. J. Biochem. 129 (1982) 179-183.

[35] M.E. Marsh, Regulation of $\mathrm{CaCO}_{3}$ formation in coccolithophores, Comp. Biochem. Physiol. B: Biochem. Mol. Biol. 136 (2003) 743-754.

[36] W.M. Balch, P. Holligan, S.G. Ackleson, K.J. Voss, Biological and optical properties of mesoscale coccolithophore blooms in the Gulf of Maine, Limnol. Oceanogr. 36 (1991) 629-643.

[37] A.M. Fichtinger-Schepman, J.P. Kamerling, J.F.G. Vliegenthart, E.W. de Jong, L. Bosch, P. Westbroek, Composition of a methylated, acidic polysaccharide associated with coccoliths of Emiliania huxleyi (Lohmann) Kamptner, Carbohydr. Res. 69 (1979) 181-189.

[38] M.E. Marsh, Polyanion-mediated mineralization - Assembly and reorganization of polysaccharides in the Golgi system of a Coccolithophorid alga during mineral deposition, Protoplasma 177 (1994) 108-122.

[39] K. Henriksen, S.L.S. Stipp, J.R. Young, M.E. Marsh, Biological control on calcite crystallization: AFM investigation of coccolith polysaccharide function, Am. Mineral. 89 (2004) 1709-1716.

[40] P.R. Van Emburg, E.W. de Jong, W.T. Daems, Immunochemical localization of a polysaccharide from biomineral structures (coccoliths) of Emiliania huxleyi, J. Ultrastruct. Mol. Struct. Res. 94 (1986) 246-259.

[41] M.E. Marsh, A.L. Ridall, P. Azadi, P.J. Duke, Galacturonomannan and Golgi-derived membrane linked to growth and shaping of biogenic calcite, J. Struct. Biol. 139 (2002) 39-45.

[42] J. Ramus, Alcian blue: A quantitative aqueous assay for algal acid and sulfated polysaccharides, J. Phycol. 13 (1977) 345-348.

[43] U. Passow, A.L. Alldredge, A dye-binding assay for the spectrophotometric measurement of transparent exopolymer particles (TEP), Limnol. Oceanogr. 40 (1995) $1326-1335$

[44] B.E. Logan, H.-P. Grossart, M. Simon, Direct observation of phytoplankton, TEP and aggregates on polycarbonate filters using brightfield microscopy, J. Plankton Res. 16 (2004) 1811-1815.

[45] D.J. Kok, L.J.M.J. Blomen, P. Westbroek, O.L.M. Bijvoet, Polysaccharide from coccoliths (CaCO3 biomineral). Influence on crystallization of calcium oxalate monohydrate, Eur. J. Biochem. 158 (1986) 167-172.

[46] J.R. Young, Variation in Emiliania huxleyi coccolith morphology in samples from the Norwegian Ehux experiment, 1992, Sarsia 79 (1994) 417-425.

[47] R. François, S. Honjo, R. Kirshfield, S. Manganini, Factors controlling the flux of organic carbon to the bathypelagic zone of the ocean, Glob. Biogeochem. Cycles 16 (2002) 1-20

[48] U. Passow, Do mineral fluxes determine particulate organic carbon fluxes or vice versa? Geochem, Geophys. Geosyst. 5 (2004) Q04002.

[49] G. Malin, S. Turner, P.S. Liss, P. Holligan, D. Harbour, Dimethylsulphide and dimethylsulphoniopropionate in the Northeast atlantic during the summer coccolithophore bloom, Deep Sea Res. Part I 40 (1993) 1487-1508.

[50] M. Steinke, G. Malin, S.D. Archer, P.H. Burkill, P.S. Liss, DMS production in a coccolithophorid bloom: evidence for the importance of dinoflagellate DMSP lyases, AME 26 (2002) 259-270. 